\title{
Development of TaqMan Real-Time PCR assays for monitoring Vibrio harveyi infection and a plasmid harbored by virulent strains in European abalone Haliotis tuberculata aquaculture
}

\author{
D. Schikorski ${ }^{\mathrm{a}}$, T. Renault ${ }^{\mathrm{a}}$, C. Paillard ${ }^{\mathrm{b}}$, A. Bidault-Toffin ${ }^{\mathrm{b}}$, D. Tourbiez ${ }^{\mathrm{a}}$, D. Saulnier ${ }^{\mathrm{a}, \star}$
}

\begin{abstract}
${ }^{a}$ Ifremer, Laboratoire de Génétique et Pathologie, Ifremer, av. du Mus de Loup, 17390 La Tremblade, France
b Laboratoire des sciences de l'Environnement Marin, CNRS UMR 6539, Institut Universitaire Européen de la Mer, Université de Bretagne Occidentale, 29280 Plouzané, France
\end{abstract}

Present address : Ifremer, Centre Ifremer du Pacifique, UMR 241 Ecosystèmes Insulaires Océaniens, Tahiti, 98719 Taravao, French Polynesia

*: Corresponding author : Denis Saulnier, Tel.: + 33689546052 ; fax: + 33689546099 ;

email address : denis.saulnier@ifremer.fr

\begin{abstract}
:
The Gram-negative bacterium Vibrio harveyi is known to be highly pathogenic for the European abalone Haliotis tuberculata, which is a gastronomically important marine gastropod with a high commercial value. Since 1998, some particular bacterial strains are described as implicated in recurrent mortality outbreaks in French farm and field stocks of abalone. Recently, a $9.6 \mathrm{~kb}$ plasmid named PVCR1, was shown to be harbored by one highly $V$. harveyi virulent ORM4 strain suggesting its involvement in virulence phenotype. Thus, we have developed in the present study two TaqMan real-time PCR assays allowing to (i) rapidly and specifically detect, by a duplex procedure and in less than two hours, both $V$. harveyi and the presence of plasmid pVCR1 from unidentified bacterial colony and (ii) to quantify both $V$. harveyi and the plasmid pVCR1 in the haemolymph of abalone or its surrounding seawater. Quantification curves of $V$. harveyi or ORM4 strain seeded in haemolymph or artificial sea water samples were equivalent showing excellent qPCR efficacies and detection level as low as $18 \mathrm{~V}$. harveyi cells-equivalent genomic DNA in a PCR reaction well. This qPCR allowed us to monitor of $V$. harveyi ORM4 strain in experimentally infected $H$. tuberculata. These diagnosis assays could provide powerful and useful tools to better understand the epidemiology of vibriosis caused by $V$. harveyi in different cultured marine species including $H$. tuberculata.
\end{abstract}

Keywords: Vibrio harveyi ; Haliotis tuberculata ; Real-time PCR ; Plasmid ; marine pathogen ; molecular diagnostic 


\section{Introduction}

The European abalone Haliotis tuberculata is a gastronomically important marine gastropod with a high commercial value but stocks of this mollusk are actually in decline in Europe (Huchette and Clavier, 2004). Numerous events of mortality have been reported in Europe in both farmed and wild populations of abalone in association with the detection of different pathogens, including the protozoan parasite Haplosporidium montforti, Rickettsia-like bacteria, or the Gram-negative bacterium Vibrio harveyi (Azevedo et al., 2006a, Azevedo et al., 2006b, Balseiro et al., 2006, Huchette and Clavier, 2004). This last bacterium has been frequently involved in recurrent mortality outbreaks occurring seasonally, at the end of warm season, since 1998 in French farms and field stocks of $H$. tuberculata (Nicolas et al., 2002). $V$. harveyi has been widely recognized as a common pathogen of many commercially cultured fish and shellfish species worldwide (Aguirre-Guzman et al., 2001, Austin and Zhang, 2006, Lee et al., 2002, Liu et al., 1996, Nishimori et al., 1998, Pass et al., 1987, Zhang and Austin, 2000) including abalone in Australia and Japan (Handlinger et al., 2005, Sawabe et al., 2007a).

Vibriosis outbreaks in $H$. tuberculata cultivated in France were shown to be driven by sea water temperature exceeding a $17^{\circ} \mathrm{C}$ threshold (Huchette and Clavier, 2004, Travers et al., 2009a) and host physiology such as gametogenesis and reduced immune defense capacities (Travers et al., 2008). Although being non-specific, clinical signs of $V$. harveyi infection encompass a loss of muscular strength occurring concomitantly with the appearance of white pustules on the foot. Subsequently, diseased animals develop a fatal septicemia leading to up to $80 \%$ mortality within a few days to 3 weeks (Travers et al., $2009 \mathrm{~b})$. Furthermore, reproduction of the disease and mortality could be achieved by experimental infection using either intramuscular injection or bath contamination with ORM4 virulent $V$. harveyi strain. Recent studies focused on the identification of virulence factors displayed by this strain. ORM4 strain was found to inhibit phagocytosis and ROS production (Travers et al., 2009b) by a mechanism presumed by authors to involve the MAP kinase signal transduction pathway displayed by abalone hemocytes. Moreover, ORM4 strain harbored a 9.6kb plasmid, named pVCR1, which was found to date only in pathogenic virulent strains of $V$. harveyi isolated during mortality outbreaks among $H$. tuberculata in France (Travers, 2008).

Rapid and reliable identification of Vibrionaceae, at the family and genus levels, can be obtained through 16S rRNA gene sequencing (Thompson et al., 2005). However, differentiation at the species level remains questionable using 16S rRNA sequence comparisons of closely related sister species sharing nearly identical $16 S$ rRNA sequences and similar phenotype features as among the Vibrio core group encompassing at least six species, Vibrio alginolyticus, Vibrio campbellii, Vibrio harveyi, Vibrio rotiferianus, Vibrio natriegens and Vibrio parahaemolyticus (Gomez-Gil et al., 2004, Thompson et al., 2009). Therefore, the taxonomy of Vibrio has been molecularly clarified through the use of diverse genomic tools, including DNA-DNA hybridization (Cho and Tiedje, 2001), amplified fragment length polymorphism (AFLP), repetitive extragenic palindromic element polymerase chain reaction (REP-PCR), random amplified polymorphic DNA (RAPD), multi-locus sequence analysis (MLSA) and whole genome sequencing (Gurtler and Mayall, 2001, Rademaker et al., 2000, Thompson et al., 2009, Thompson et al., 2004, Versalovic et al., 1991). However, these techniques are time consuming and appear not well adapted to perform rapid diagnostic tests in the context of disease surveillance and prevention in aquaculture facilities.

The goal of the current study was the development and evaluation of two TaqMan PCR assays that could provide rapid, specific, sensitive and quantitative methods for the detection of $V$. harveyi strains, harboring or not the suspected virulent pVCR1 plasmid, in either pure cultures or in the hemolymph of the European abalone $H$. tuberculata and its surrounding 
seawater. For this purpose, two pairs of primers and probes were designed, (i) the first one targeting a specific region of the tox $R$ gene, a widely studied housekeeping gene, to detect only $V$. harveyi species among the Vibrio core group, and (ii) the second one targeting a region of the pVCR1 plasmid sequence corresponding to the parA gene which encodes a putative protein implicated in the plasmid repartition and supposed to be well conserved (Davis et al. 1992, Edgar et al., 2006). The real-time PCR protocol quantifying $V$. harveyi cells was used to monitor the dynamics of infection of $H$. tuberculata abalones that were previously experimentally infected with a virulent ORM4 strain.

\section{Material and methods}

\subsection{Abalone and hemolymph collection}

Juveniles (40 mm $\pm 1.0,2$ years old) of Haliotis tuberculata were purchased from the hatchery of France Haliotis (Plouguerneau, France) and transferred in the Ifremer's facilities (Laboratoire de Génétique et Pathologie, La Tremblade, France). Animals were acclimated in $50 \mathrm{~L}$ polyethylene tanks with an open seawater circuit at $14-15^{\circ} \mathrm{C}$ under continuous aeration. During this period, abalones were fed ad libitum with marine algae diet of Palmaria palmata.

Two weeks before to be used for the different experimental assays, groups of 10 abalone were transferred in small aquaria filled with 5 liters of $1 \mu \mathrm{m}$ filtered natural seawater. Abalone were slowly acclimated at $19^{\circ} \mathrm{C}\left(0.5^{\circ} \mathrm{C}\right.$ per day) in absence of feeding. Seawater was continuously aerated and daily renewed. Abalone (control and experimentally infected animals) were previously anesthetized by bathing during 10 min in seawater containing $3 \%$ of absolute ethanol. In time relaxed, hemolymph was withdrawn from the cephalic arterial sinus located at the anterior extremity of the pedal muscle using a $1 \mathrm{~mL}$ syringe fitted with a 20-G needle.

\subsection{Bacterial strains and culture conditions}

Seventeen reference strains of Vibrio species phylogenetically closed to $V$. harveyi LMG 4044 type strain and eight $V$. harveyi strains isolated from Haliotis sp. were used in this study (Table 1). References strains were purchased from DSMZ, CIP and LMG collections, two isolates S35 and S20 were generously provided by T. Sawabe (Sawabe et al., 2007a). Other strains were obtained from samples collected at Larmor Baden in Brittany (France). They were identified by sequencing of $16 \mathrm{~S}$ rRNA (Thompson et al., 2005) and toxR gene detection by PCR (Conejero and Hedreyda, 2003). All bacterial strains were cultured in Luria-Bertani (LB) Broth medium complemented with $2 \% \mathrm{NaCl}(\mathrm{w} / \mathrm{v})$ salt (LBS) at $28^{\circ} \mathrm{C}$ during $18 \mathrm{~h}$ under constant shaking. They originated from bacterial stock culture stored at $-80^{\circ} \mathrm{C}$ and prepared as $15 \%(\mathrm{v} / \mathrm{v})$ glycerol suspensions in LBS.

\subsection{Bacterial template DNA}

Two methods were used to extract bacterial DNA as previously described (Saulnier et al., 2009). The boiling method was used for specificity evaluation of real-time PCR assay using a single bacterial colony as DNA template for qPCR. In contrast, for the detection and quantification of toxR and parA bacterial genes, total DNA was extracted from samples constituting ten-fold serial dilutions of artificially spiked $V$. harveyi ORM4 cells performed either in Sterile Artificial Sea-Water (SASW, 2.3\% NaCl, $20 \mathrm{mM} \mathrm{KCl,} 5 \mathrm{mM} \mathrm{MgSO}$, $2 \mathrm{mM}$ $\mathrm{CaCl}_{2}$ ) or in freshly collected abalone hemolymph pool (see section, below). DNA extraction was carried out using the QIAamp DNA mini kit (QIAgen) combined with the use of the QIAcube automate according to the manufacturer's recommendations. Briefly, samples of $200 \mu \mathrm{L}$ were centrifuged at $10,000 \mathrm{~g}$ at $4^{\circ} \mathrm{C}$ during $5 \mathrm{~min}$. Pellets, containing bacteria and/or 
haemocytes, were digested overnight on a rocking platform at $56^{\circ} \mathrm{C}$ by addition of $180 \mu \mathrm{L}$ of ATL buffer supplied with $20 \mu \mathrm{L}$ of proteinase $\mathrm{K}$. Lysates were transferred into a $2 \mathrm{~mL}$ microcentrifuge tube. DNA extraction with QIAamp Mini spin columns was carried out using a QIAcube automate. Final elution of DNA was performed with $200 \mu \mathrm{L}$ of ultra pure water, and samples were then stored at $-20^{\circ} \mathrm{C}$. DNA yield and purity were determined by spectrophotometry (Eppendorf).

\subsection{PCR primers and fluorogenic probes design}

In order to target specifically $V$. harveyi species, the tox $R$ oligonucleotide and probe sequences were designed in variable regions deduced from the sequence alignment analysis of numerous Vibrionaceae tox $R$ genes available in GenBank database. Based on the common sequence of 22 tox $R$ genes of Vibrio harveyi, two primers and one probe were designed.

The parA oligonucleotide sequences and probe were designed to target exclusively the parA like gene of pVCR1 plasmid (Accession number KC306506), encoding a putative plasmid partition protein sharing $59 \%$ of identities with ParA family protein of Acinetobacter radioresistens (ZP_05362210). Primer-3 software was used to design real-time PCR probes and primers, taking into account optimal thermal and chemical conditions for PCR amplification compatible with probe hydrolysis based qPCR (Table 2). The tox $R$ probe was dually labeled with 5'-reporter dye Texas Red (wavelength emission at $602 \mathrm{~nm}$ ) and a downstream 3'-quencher dye BHQ-2. The parA probe consists of an oligonucleotide dually labeled with 5'-reporter dye 6-FAM (wavelength emission at $502 \mathrm{~nm}$ ) and a downstream 3'quencher dye Tamra. The specificity of the probes and primers was assessed by using a BLAST (Basic Local Alignment Search Tool) to ensure that they amplify only parA and tox $R$ genes from pVCR1 plasmid and $V$. harveyi respectively with no homology to other known sequences found in GenBank and EMBL databases. The two probes emitting light at two distinct wavelengths and the two couples of primers were purchased from Eurogentec.

Real-time PCR assays were conducted on a MX3000 Thermocycler (Stratagene) using Brilliant $\AA$ qPCR Core Reagent Kit (Stratagene). Each reaction was run in duplicate in a final volume of $25 \mu \mathrm{L}$ containing various concentrations of DNA sample $(5 \mu \mathrm{L}), 5 \mathrm{mM} \mathrm{MgCl} 2,200$ $\mu \mathrm{M}$ of each dNTP, $300 \mathrm{nM}$ of each primer, $200 \mathrm{nM}$ of oligonucleotidic probe and 1.25 units of hot start Sure Taq polymerase (Stratagene). The thermal cycle was performed with a two step PCR protocol: 1 cycle at $95^{\circ} \mathrm{C}$ for 10 min followed by 40 cycles at $95^{\circ} \mathrm{C}$ for $15^{\circ} \mathrm{C}$ and $60^{\circ} \mathrm{C}$ for $90 \mathrm{~s}$. Fluorescence intensity was expressed in delta reporters (dR) after background saturation. Threshold Cycle $(\mathrm{Ct})$ value corresponds to the PCR cycle number at which an increase in reporter fluorescence above a baseline signal was first detected.

\subsection{Quantification of $\boldsymbol{V}$. harveyi in artificially spiked samples}

An early stationary phase centrifuged pure culture of $V$. harveyi ORM4 strain was centrifuged $(10 \mathrm{~min}$ at $3200 \mathrm{~g})$, and the bacterial pellet suspended in a determined volume of SASW in order to obtain the desired concentration of bacterial cells. Bacterial cells were enumerated in a Malassez counting chamber and ten-fold serial dilutions (from $10^{-3}$ to $10^{-8}$ ) in SASW were performed to generate the first standard curve. For the second standard curve, SASW was replaced by abalone hemolymph. Each DNA extract was tested in triplicate by real-time PCR. Quantification of bacterial cells by real time PCR assays in spiked samples was compared with enumeration of bacterial cells using a Malassez counting chamber. 


\subsection{Experimental infection of $\boldsymbol{H}$. tuberculata}

After being anesthetized by bathing during $5 \mathrm{~min}$ in $5 \%$ absolute ethanol-seawater, 25 mature abalones were experimentally infected by injection of $100 \mu \mathrm{L}$ of $V$. harveyi ORM4 bacterial suspension, at $1.10^{5}$ cells per $\mathrm{mL}$ concentration, in the foot of animals. Inoculated abalones were randomly distributed in five $5 \mathrm{~L}$ aquaria supplied in filtered $(1 \mu \mathrm{m})$ seawater at $14-15^{\circ} \mathrm{C}$ without food supply and under continuous aeration. Seawater was renewed every day. Negative control was constituted a batch of 5 individuals injected with $100 \mu \mathrm{L}$ of SASW. In order to evaluate the kinetics of infection, one individual was collected in each aquarium at $24,48,72,96$ and $120 \mathrm{~h}$. A volume of $200 \mu \mathrm{L}$ of hemolymph per animal was withdrawn, then centrifuged at $10,000 \mathrm{~g}$ for $2 \mathrm{~min}$ and DNA extracted. The presence of $V$. harveyi ORM4 was determined and quantified in collected samples by real-time PCR using the appropriate standard curve.

\section{Results}

\subsection{Specificity of the duplex real-time PCR}

Real-time PCR assays carried out for the detection of V.harveyi and pVCR1 plasmid DNAs were carried out simultaneously on 17 different bacterial strains (Table 1) thanks to a duplex TaqMan procedure adding the two couples of primers and the two differently labeledfluorogenic probes in the PCR reaction mixture targeting tox $R$ and parA genes.

The species specificity of the real-time PCR assay developed for the identification of $V$. harveyi was evaluated on nine bacterial strains phylogenically related to $V$. harveyi, including two reference strains, LMG $4044^{\top}$ and LMG7890, isolated from the amphipod Talorchestia sp and the brown shark Carcharhinus plumbeus, respectively and 8 bacterial strains, isolated from the European abalone Haliotis tuberculata or closest abalone environment (algae) $(n=6)$ and from the Japanese abalone Haliotis discus hannai $(\mathrm{n}=2)$.

Real-time PCR results obtained showed that all tested $V$. harveyi strains were positive $(n=10)$ for the detection of the toxR gene, including the LMG4044 ${ }^{\top}$ and LMG7890 V. harveyi strains and the different $V$. harveyi strains isolated from $H$. tuberculata or algae closed to moribund abalone and $H$. discus during mortality outbreaks (Table 1). In contrast, no positive amplification signals were obtained with other bacterial reference strains phylogenically closed to $V$. harveyi, as for $V$. campbellii bacteria. Results of real-time PCR for the detection of pVCR1 plasmid revealed two positive bacterial strains related to $V$. harveyi species including the virulent ORM4 strain (Table 1). Amplified PCR product sizes obtained from $V$. harveyi ORM4 DNA templates were verified by gel electrophoresis visualizing an attempted size deduced from nucleotidic sequence of 162-bp and 168-bp amplicons for tox $R$ and parA genes, respectively (Figure 1).

\subsection{Sensitivity of the real-time PCR assays}

Standard curves for the toxR gene quantification were carried out in SASW or hemolymph samples artificially spiked with pure bacterial suspension of $V$. harveyi ORM4 strain of known concentration as determined by Malassez counting method. Ten fold bacterial dilutions ranging from $3.7 \times 10^{3}$ to $3.7 \times 10^{8}$ cells $\mathrm{mL}^{-1}$ were prepared in these two diluents. Taking into account the different DNA extraction steps and the use of $5 \mu \mathrm{L}$ of DNA sample for real-time PCR, genomic DNA extracted from $1.8 \times 10^{1}$ to $1.8 \times 10^{6}$ bacteria was added to each PCR reaction mixture. The threshold cycle $(\mathrm{Ct})$ values deduced from real-time PCR amplifications on purified DNA extracts were plotted to the number of bacteria initially presents in PCR templates. 
Both quantification curves achieved for each gene were similar and exhibited excellent correlation coefficients and high PCR reaction efficacies. For the tox $R$ gene, correlations of $r^{2}=0.988$ and $r^{2}=0.999$ and efficacies of $100 \%$ and $103.9 \%$ were obtained in SASW and hemolymph spiked samples, respectively (Figure 2). Concerning the parA gene, correlations of $r^{2}=0.998$ and $r^{2}=1$ and efficacies of $98 \%$ and $100.2 \%$ were obtained in SASW and hemolymph spiked samples, respectively (Figure 3 ).

Comparison between the different curves revealed that the nature of sample, SASW versus hemolymph, had no effect on the detection levels of $V$. harveyi in the range of cell dilutions used in this study. The threshold sensitivity of these quantification methods targeting either toxR or parA genes, is given by the lower bacterial concentration tested, and corresponds to a minimal $V$. harveyi cell number-equivalent genomic DNA of 18 in the PCR reaction.

\subsection{Kinetics of infection during abalone challenge}

The quantification of bacterial DNA amounts present in hemolymph samples from abalone was estimated by reporting $\mathrm{Ct}$ values to the standard quantification curve of the tox $R$ gene previously established for hemolymph. Real-time PCR assay results showed that four, three, three, five and five individuals among five were detected as positive at 24h, 48h, 72h, 96 and $120 \mathrm{~h}$ post infection respectively (Figure 4). Bacterial loads of seven infected abalones sampled at $96 \mathrm{~h}$ and $120 \mathrm{~h}$ post infection ranged from $3.8 \times 10^{3}$ cells $\mathrm{mL}^{-1}$ to $5 \times 10^{6}$ cells $\mathrm{mL}^{-1}$ of hemolymph. Nevertheless several bacterial concentrations were not calculated because obtained $\mathrm{Ct}$ values were above the linear working range of the standard curve. During all the time course of the experiment, no positive signal was detected in control animals and no mortality was recorded.

\section{Discussion}

In this work, we developed a rapid and quantitative diagnostic test by real-time PCR allowing the detection of both $V$. harveyi bacteria and pVCR1 plasmidic DNAs. This protocol was elaborated using two pairs of primers and TaqMan probes targeting in one hand the tox $R$ gene, a widely used gene in multi-locus sequence typing approach for molecular phylogeny and identification of Vibrio (Pang et al., 2006, Rosec et al., 2009, Takahashi et al., 2005a), and in another hand a specific region of the pVCR1 plasmid coding the putative parA product. Primers and probes were used simultaneously for duplex real-time PCR detection assays on bacterial colony DNA previously extracted by rapid boiling method or separately for quantification issues. Indeed, for quantification, the use of both probes and couple of primers in the same PCR reaction mixture during our sensitivity assays was shown to adversely impact the efficacy of the TaqMan real-time PCR assay (data not shown).

Most of scientific publications dealing with rapid, sensitive and specific molecular identification of Vibrio species use PCR technique. Concerning Vibrio harveyi, several PCR assays have been developed (Conejero and Hedreyda, 2003, Fukui and Sawabe, 2008, Pang et al., 2006) aiming to facilitate disease prevention and surveillance in cultured marine animals. More recently Cao et al. (2010) successfully developed a novel nucleic acid amplification diagnostic method based on loop-mediated isothermal amplification (LAMP) to detect $V$. harveyi infection in the cultured gastropod Babylonia areolata. Nevertheless all these methods fail to produce quantitative measurements of $V$. harveyi bacterial load in tested samples. According to our knowledge a few number of real-time PCR assays allowing specific detection and quantification of Vibrio DNA have been reported in the literature (Saulnier et al., 2009). These reports concern mainly Vibrio sp. inducing public health hazard, e.g. Vibrio vulnificus (Takahashi et al., 2005a), Vibrio parahaemolyticus (Qin et al., 2008, Takahashi et al., 2005b) and V. cholerae (Gubala, 2006). Fukui and Sawabe (2008) 
developed a real-time PCR assay on $V$. harveyi targeting the 16S rRNA gene. Nevertheless, the high conservation of nucleotidic sequences of this gene in Vibrionacea resulted in the failure for some phylogenetically closed Vibrio species, $V$. rotiferianus in particular, to find divergent nucleotidic sequence for PCR primer annealing. As a consequence the quantification of $V$. harveyi in mixed cultures of $V$. harveyi and $V$. rotiferianus was underestimated due to competition between both DNA templates during real time PCR even if the specificity of real time PCR was restored by TaqMan probe (Fukui and Sawabe, 2008). In the present study, we have developed a new real-time PCR protocol to detect exclusively $V$. harveyi bacteria and not the closed species belonging to $V$. harveyi group and encompassing at least 5 different species, e.g. $V$. rotiferianus, $V$. campbellii, $V$. parahaemolyticus, $V$. alginolyticus, Vibrio mytili, as revealed by a multi-locus sequence typing study including 8 housekeeping genes (Sawabe et al., 2007b, Thompson et al., 2007). ToxR protein coding gene was targeted because its demonstrated higher inter-species discriminatory power than 16S rRNA gene (Franco and Hedreyda, 2006, Montieri et al., 2010) when sequence of $V$. harveyi and closely related strains genes were aligned and compared.

The specificity of PCR primers and TaqMan probe designed was determined by real-time PCR assays carried out on DNA samples extracted from pure culture of different bacterial strains belonging to the $V$. harveyi group. Only positive fluorescence signals were obtained for DNA samples extracted from the virulent ORM4 reference strain, from the $V$. harveyi reference strains (LMG 7890 and LMG $4044^{\top}$ ) or from different bacterial strains belonging to the $V$. harveyi, after $16 \mathrm{~S}$ rRNA sequencing and tox $R$ gene detection by conventional PCR (Conejero and Hedreyda, 2003). In this study, no signal in the other species closed to $V$. harveyi, such as $V$. rotiferianus, $V$. campbellii, $V$. parahaemolyticus, $V$. alginolyticus, $V$. mytili and reference type strains Vibrio coralliilyticus and Vibrio brasiliensis was detected even at high threshold cycle value $(\mathrm{Ct}>40)$.

For the parA gene amplification, positive signals were detected for DNA samples extracted from only two bacterial strains of $V$. harveyi, the virulent reference strain ORM4 isolated from moribund $H$. tuberculata abalone and the $V$. harveyi strain LEM/07/014 isolated from algae closed to moribund abalone. Contrarily to S35, S20 and LEM/07/001, LEM/07/004 bacterial strains, strain LEM/07/014 is able to induce high mortality after abalone experimental infection (C. Paillard, pers. comm.). No real-time PCR signals were generated with DNA samples extracted either from other $V$. harveyi strains isolated from algae closed to moribund abalone, LEM/07/0012 and LEM/07/0013, or from other tested Vibrio reference strains. This result demonstrated the specificity of PCR primers and TaqMan probe designed to target the parA gene of the pVCR1 plasmid, with no detectable background signals that could be generated by the presence of bacterial genomic DNA in the tested total DNA extracts.

The standard curves generated by real-time PCR in 10-fold dilutions of SASW or abalone hemolymph samples artificially spiked with the virulent ORM4 strain of $V$. harveyi demonstrated excellent coefficients of correlation for the PCR primers and TaqMan probe used. Moreover, both standard curves were perfectly stackable, indicating that presence of complex DNA matrix in hemolymph DNA samples had no effect on both real time PCR efficiency and sensitivity and that DNA extraction procedure for hemolymph samples was satisfactory. The comparison between $\mathrm{Ct}$ values recorded for standard curves generated with each couple of PCR primers and TaqMan probes allowed us to estimate the copy number of plasmid per bacteria. Indeed, for a same sample and whatever the considered dilution, Ct values generated for single-copy tox $R$ gene are less than 2 cycles more than $\mathrm{Ct}$ values obtained for parA gene. Thus, the copy number of pVCR1 per $V$. harveyi cell can be consequently estimated around 2-4 copies per bacteria cell, which make pVCR1 in ORM4 as a very low copy plasmid. A large range of plasmids is often maintained at very low copy numbers per cell such as for the pJM1 plasmid in Vibrio anguillarum cells (Di Lorenzo et al., 2003). 
Whatever the nature of tested samples (SASW or hemolymph), the detection limits of the real-time PCR assays were estimated at $1.8 \times 10^{1}$ bacteria per well. Taking into account the dilution factor employed in this study to extract DNA of biological samples, the detection limit corresponds to a minimal bacterial concentration of $3.7 \times 10^{3} \mathrm{~mL}^{-1}$ of SASW or hemolymph. Greater detection limits have been reported in the literature concerning other real-time TaqMan PCR protocols targeting other Vibrio species in mollusks, such as for the detection methods for Vibrio aestuarianus or $V$. vulnificus showing detection limits estimated at $2,3 \times 10^{2}$ and $1.6 \times 10^{2}$ bacteria $\mathrm{mL}^{-1}$ which were extrapolated to correspond to 6 and 1.6 cells per PCR well, respectively (Campbell and Wright, 2003, Panicker and Bej, 2005, Saulnier et al., 2009). Thus, practical modifications to increase sensibility of our real time PCR would consist in developing procedures to concentrate bacteria of samples prior to DNA extraction.

Using an invasive way of infection, by experimental injection of ORM4 cells in apparently healthy $H$. tuberculata abalone, we showed in the present study that hemolymph of abalone is a good target tissue to monitor infection, this tissue having the advantage to be not destructive for $H$. tuberculata, allowing broodstock screening to check the presence or absence of virulent $V$. harveyi in indoor breeding structures. The number of infected animals as well as ORM4 bacterial loads in positive animals increased over time, with values ranging from $3.8 \times 10^{3} \mathrm{~V}$. harveyi cells $\mathrm{mL}^{-1}$ to $5 \times 10^{6}$ cells $\mathrm{mL}^{-1}$. Furthermore 5 abalones among 15 tested were heavily infected by more than $1 \times 10^{4} \mathrm{~V}$. harveyi cells $\mathrm{mL}^{-1}$ between $72 \mathrm{~h}$ and $120 \mathrm{~h}$ post infection, whereas all the ten abalones tested for the first $48 \mathrm{~h}$ of our survey were either found not infected $(n=3)$ or infected at bacterial load lower than $3.7 \times 10^{3}$ cells $\mathrm{mL}^{-1}$ during our survey.

In conclusion, the developed protocol constitutes a useful molecular tool allowing to detect and to quantify rapidly virulent $V$. harveyi strains in the European abalone $H$. tuberculata that could contribute to safety measures in the production of virulent $V$. harveyi-free broodstock in indoor facilities.

\section{Acknowledgments}

This work was supported by the European project SUDEVAB (Sustainable Development of European SMEs Engaged in Abalone Aquaculture) under the EC's Seventh Framework Programme (FP7, 2007-2013). The authors of this paper would like to thank Dr Sylvain Huchette and all the team of the abalone farm France Haliotis for their contribution, and cooperation, and kindness. We are thankful to M.A. Travers for her critical reading of the manuscript.

\section{References}

Aguirre-Guzman, G., Vazquez-Juarez, R., Ascencio, F., 2001. Differences in the susceptibility of American white shrimp larval substages (Litopenaeus vannamei) to four vibrio species. J. Invertebr. Pathol. 78, 215-219.

Austin, B., Zhang, X.H., 2006. Vibrio harveyi: a significant pathogen of marine vertebrates and invertebrates. Lett. Appl. Microbiol. 43, 119-124.

Azevedo, C., Balseiro, P., Casal, G., Gestal, C., Aranguren, R., Stokes, N.A., Carnegie, R.B., Novoa, B., Burreson, E.M., Figueras, A., 2006a. Ultrastructural and molecular characterization of Haplosporidium montforti $n$. sp., parasite of the European abalone Haliotis tuberculata. J. Invertebr. Pathol. 92, 23-32. 
Azevedo, C., Conchas, R.F., Tajdari, J., Montes, J., 2006b. Ultrastructural description of new Rickettsia-like organisms in the commercial abalone Haliotis tuberculata (Gastropoda: Haliotidae) from the NW of Spain. Dis. Aquat. Organ. 71, 233-237.

Balseiro, P., Aranguren, R., Gestal, C., Novoa, B., Figueras, A., 2006. Candidatus Xenohaliotis californiensis and Haplosporidium montforti associated with mortalities of abalone Haliotis tuberculata cultured in Europe. Aquaculture. 258, 63-72.

Campbell, M.S., Wright, A.C., 2003. Real-time PCR analysis of Vibrio vulnificus from oysters. Appl. Environ. Microbiol. 69, 7137-7144.

Cao, Y.T., Wu, Z.H., Jian, J.C., Lu, Y.S., 2010. Evaluation of a loop-mediated isothermal amplification method for the rapid detection of Vibrio harveyi in cultured marine shellfish. Lett. Appl. Microbiol. 51, 24-29.

Cho, J.C., Tiedje, J.M., 2001. Bacterial species determination from DNA-DNA hybridization by using genome fragments and DNA microarrays. Appl. Environ. Microbiol. 67, 3677-3682.

Conejero, M.J., Hedreyda, C.T., 2003. Isolation of partial toxR gene of Vibrio harveyi and design of toxR-targeted PCR primers for species detection. J. Appl. Microbiol. 95, 602-611.

Davis, M.A., Martin, K.A., Austin, S.J., 1992. Biochemical activities of the parA partition protein of the P1 plasmid. Mol. Microbiol. 6, 1141-1147.

Di Lorenzo, M., Stork, M., Tolmasky, M.E., Actis, L.A., Farrell, D., Welch, T.J., Crosa, L.M., Wertheimer, A.M., Chen, Q., Salinas, P., Waldbeser, L., Crosa, J.H., 2003. Complete sequence of virulence plasmid pJM1 from the marine fish pathogen Vibrio anguillarum strain 775. J. Bacteriol. 185, 5822-5830.

Edgar, R., Biek, D., Yarmolinsky, M., 2006. P1 plasmid partition: in vivo evidence for the ParA- and ParB-mediated formation of an anchored parS complex in the absence of a partner parS. Mol. Microbiol. 59, 276-287.

Franco, P.F., Hedreyda, C.T., 2006. Amplification and sequence analysis of the full length toxR gene in Vibrio harveyi. J. Gen. Appl. Microbiol. 52, 281-287.

Fukui, Y., Sawabe, T., 2008. Rapid detection of Vibrio harveyi in seawater by real-time PCR. Microbes Environ. 23, 172-176.

Gomez-Gil, B., Soto-Rodriguez, S., Garcia-Gasca, A., Roque, A., Vazquez-Juarez, R., Thompson, F.L., Swings, J., 2004. Molecular identification of Vibrio harveyi-related isolates associated with diseased aquatic organisms. Microbiology. 150, 1769-1777.

Gubala, A.J., 2006. Multiplex real-time PCR detection of Vibrio cholerae. J. Microbiol. Methods. 65, 278-293.

Gurtler, V., Mayall, B.C., 2001. Genomic approaches to typing, taxonomy and evolution of bacterial isolates. Int. J. Syst. Evol. Microbiol. 51, 3-16.

Handlinger, J., Carson, J., Donachie, L., Gabor, L., Taylor, D., 2005. Bacterial Infection in Tasmanian Farmed Abalone: Causes, Pathology, Farm Factors and Control Options. In: Walker, P., Lester, R., Bondad-Reantaso, M.G. (Eds), Diseases in Asian Aquaculture V. Fish Health Section, Asian Fisheries Society, Manila, pp. 289-299.

Huchette, S.M.H., Clavier, J., 2004. Status of the ormer (Haliotis tuberculata L.) industry in Europe. J. shellfish res. 23, 951-955.

Lee, K.K., Liu, P.C., Chuang, W.H., 2002. Pathogenesis of gastroenteritis caused by Vibrio carchariae in cultured marine fish. Mar. Biotechnol. (NY). 4, 267-277.

Liu, P.C., Lee, K.K., Yii, K.C., Kou, G.H., Chen, S.N., 1996. Isolation of Vibrio harveyi from diseased kuruma prawns Penaeus japonicus. Curr. Microbiol. 33, 129-132.

Montieri, S., Suffredini, E., Ciccozzi, M., Croci, L., 2010. Phylogenetic and evolutionary analysis of Vibrio parahaemolyticus and Vibrio alginolyticus isolates based on toxR gene sequence. New Microbiol. 33, 359-372.

Nicolas, J.L., Basuyaux, O., Mazurie, J., Thebault, A., 2002. Vibrio carchariae, a pathogen of the abalone Haliotis tuberculata. Dis. Aquat. Organ. 50, 35-43.

Nishimori, E., Hasegawa, O., Numata, T., Wakabayashi, T., 1998. Vibrio carchariae causes mass mortalities in Japanese abalone, Sulculus diversicolor supratexta. Fish Pathol. 33, 495-502.

Pang, L., Zhang, X.H., Zhong, Y., Chen, J., Li, Y., Austin, B., 2006. Identification of Vibrio harveyi using PCR amplification of the toxR gene. Lett. Appl. Microbiol. 43, 249-255. 
Panicker, G., Bej, A.K., 2005. Real-time PCR detection of Vibrio vulnificus in oysters: comparison of oligonucleotide primers and probes targeting vvhA. Appl. Environ. Microbiol. 71, 5702-5709.

Pass, D.A., Dybdahl, R., Mannion, M.M., 1987. Investigations into the causes of mortality of the pearl oyster, Pinctada maxima (Jamson), in western Australia. Aquaculture. 65, 149-169.

Qin, Y., Wu, H., Xiao, X., Yang, X., Zhang, J., Yu, Y., Li, H., 2008. Rapid detection of Vibrio parahaemolyticus by TaqMan-based real-time PCR assay targeting the tox $R$ gene. Sheng Wu Gong Cheng Xue Bao. 24, 1837-1842.

Rademaker, J.L., Hoste, B., Louws, F.J., Kersters, K., Swings, J., Vauterin, L., Vauterin, P., de Bruijn, F.J., 2000. Comparison of AFLP and rep-PCR genomic fingerprinting with DNADNA homology studies: Xanthomonas as a model system. Int. J. Syst. Evol. Microbiol. 50, 665-677.

Rosec, J.P., Simon, M., Causse, V., Boudjemaa, M., 2009. Detection of total and pathogenic Vibrio parahaemolyticus in shellfish: comparison of PCR protocols using $\mathrm{pR} 72 \mathrm{H}$ or toxR targets with a culture method. Int. J. Food. Microbiol. 129, 136-145.

Saulnier, D., De Decker, S., Haffner, P., 2009. Real-time PCR assay for rapid detection and quantification of Vibrio aestuarianus in oyster and seawater: a useful tool for epidemiologic studies. J. Microbiol. Methods. 77, 191-197.

Sawabe, T., Inoue, S., Fukui, Y., Yoshie, K., Nishihara, Y., Miura, H., 2007a. Mass mortalities of Japonese abalone Haliotis discus hannai caused by Vibrio harveyi infection. Microbes Environ. 22, 300-308.

Sawabe, T., Kita-Tsukamoto, K., Thompson, F.L., 2007b. Inferring the evolutionary history of vibrios by means of multilocus sequence analysis. J. Bacteriol. 189, 7932-7936.

Takahashi, H., Hara-Kudo, Y., Miyasaka, J., Kumagai, S., Konuma, H., 2005a. Development of a quantitative real-time polymerase chain reaction targeted to the tox $R$ for detection of Vibrio vulnificus. J. Microbiol. Methods. 61, 77-85.

Takahashi, H., Iwade, Y., Konuma, H., Hara-Kudo, Y., 2005b. Development of a quantitative real-time PCR method for estimation of the total number of Vibrio parahaemolyticus in contaminated shellfish and seawater. J. Food. Prot. 68, 1083-1088.

Thompson, C.C., Vicente, A.C., Souza, R.C., Vasconcelos, A.T., Vesth, T., Alves, N., Jr., Ussery, D.W., lida, T., Thompson, F.L., 2009. Genomic taxonomy of Vibrios. BMC Evol. Biol. 9, 258.

Thompson, F.L., lida, T., Swings, J., 2004. Biodiversity of vibrios. Microbiol. Mol. Biol. Rev. $68,403-431$.

Thompson, F.L., Gevers, D., Thompson, C.C., Dawyndt, P., Naser, S., Hoste, B., Munn, C.B., Swings, J., 2005. Phylogeny and molecular identification of vibrios on the basis of multilocus sequence analysis. Appl. Environ. Microbiol. 71, 5107-5115.

Thompson, F.L., Gomez-Gil, B., Vasconcelos, A.T., Sawabe, T., 2007. Multilocus sequence analysis reveals that Vibrio harveyi and $V$. campbellii are distinct species. Appl. Environ. Microbiol. 73, 4279-4285.

Travers, M.A., Le Goic, N., Huchette, S., Koken, M., Paillard, C., 2008a. Summer immune depression associated with increased susceptibility of the European abalone, Haliotis tuberculata to Vibrio harveyi infection. Fish Shellfish Immun. 25, 800-808.

Travers, M.A., 2008b. PhD Thesis. Interaction de la bactérie Vibrio harveyi avec son hôte, l'ormeau Haliotis tuberculata: approches physiologiques, cellulaires et moléculaires. Université de Bretagne Occidentale, Brest, France.

Travers, MA., Basuyaux, O., Le Goïc N., Huchette, S., Nicolas, J.L., Koken, M., Paillard, C. 2009a "Influence of temperature and spawning effort on Haliotis tuberculata susceptibility to Vibrio harveyi: an example of emerging vibriosis linked to global warming." Global Change Biol. 15, 1365-1376.

Travers, M.A., Le Bouffant, R., Friedman, C.S., Buzin, F., Cougard, B., Huchette, S., Koken, M., Paillard, C., 2009b. Pathogenic Vibrio harveyi, in contrast to non-pathogenic strains, intervenes with the p38 MAPK pathway to avoid an abalone haemocyte immune response. J. Cell. Biochem. 106, 152-160. 
Versalovic, J., Koeuth, T., Lupski, J.R., 1991. Distribution of repetitive DNA sequences in eubacteria and application to fingerprinting of bacterial genomes. Nucleic Acids. Res. 19, 6823-6831.

Zhang, X.H., Austin, B., 2000. Pathogenicity of Vibrio harveyi to salmonids. J. Fish Dis. 23, 93-102.

\section{Tables}

Table 1: Specificity of the Taqman real-time PCR assays for the detection of toxR and parA genes according to bacterial strains isolated from different origins and hosts.

\begin{tabular}{|c|c|c|c|c|}
\hline \multirow[t]{2}{*}{ Strain } & \multirow{2}{*}{$\begin{array}{l}\text { Vibrio } \\
\text { species }\end{array}$} & \multirow[t]{2}{*}{ Source and context of isolation } & \multicolumn{2}{|c|}{$\begin{array}{c}\text { Real-time PCR results } \\
(+/-)\end{array}$} \\
\hline & & & tox $R$ gene & parA gene \\
\hline ORM4 & V. harveyi & $\begin{array}{l}\text { Isolated from moribund abalone, France } 1998 \\
\text { (Nicolas et al., 2002) }\end{array}$ & + & + \\
\hline LEM/07/001 & V. harveyi & $\begin{array}{l}\text { Isolated from moribund abalone no } 7 \text {, France } \\
30 / 07 / 2007\end{array}$ & + & - \\
\hline LEM/07/004 & V. harveyi & $\begin{array}{l}\text { Isolated from moribund abalone no } 9 \text {, France } \\
30 / 07 / 2007\end{array}$ & + & - \\
\hline LEM/07/012 & V. harveyi & $\begin{array}{l}\text { Isolated from algae closed to moribund } \\
\text { abalone } 01 / 08 / 2007\end{array}$ & + & - \\
\hline LEM/07/013 & V. harveyi & $\begin{array}{l}\text { Isolated from algae closed to moribund } \\
\text { abalone France (Morbihan) } 01 / 08 / 2007\end{array}$ & + & - \\
\hline LEM/07/014 & V. harveyi & $\begin{array}{l}\text { Isolated from algae closed to moribund } \\
\text { abalone France (Morbihan) } 01 / 08 / 2007\end{array}$ & + & + \\
\hline S35 & V. harveyi & $\begin{array}{l}\text { Isolated from dead abalone (Haliotis discus } \\
\text { hannai), Japan }\end{array}$ & + & - \\
\hline S20 & V. harveyi & $\begin{array}{l}\text { Isolated from dead abalone (Haliotis discus } \\
\text { hannai), Japan }\end{array}$ & + & - \\
\hline LMG $4044^{\top}$ & V. harveyi & $\begin{array}{l}\text { Isolated from dead amphipod (Talorchestia } \\
\text { sp.), Massachusetts USA }\end{array}$ & + & - \\
\hline LMG 7890 & V. harveyi & $\begin{array}{l}\text { Isolated from brown shark (Carcharhinus } \\
\text { plumbeus) kidney, Baltimore, USA }\end{array}$ & + & - \\
\hline DSMZ $17184^{\top}$ & V. brasiliensis & Bivalve larvae (Nodipecten nodosus), Brazil & - & - \\
\hline DSMZ $17186^{\top}$ & V. rotiferianus & Rotifer Brachionus plicatilis culture, Belgium & - & - \\
\hline DSMZ $19137^{\top}$ & V. mytili & Mussels (Mytilus edulis), Spain & - & - \\
\hline LMG $11216^{\top}$ & V. campbellii & $\begin{array}{l}\text { Isolated from seawater collected at a depth of } \\
800 \mathrm{~m}\left(20^{\circ} 30^{\prime} \mathrm{N}, 157^{\circ} 30^{\prime} \mathrm{E}\right)\end{array}$ & - & - \\
\hline LMG $4409^{\top}$ & V. alginolyticus & $\begin{array}{l}\text { Isolated from spoiled horse mackerel } \\
\text { (Trachurus trachurus) causing food poising, } \\
\text { Japan }\end{array}$ & - & - \\
\hline LMG $2850^{\top}$ & $\begin{array}{c}\text { V. para- } \\
\text { haemolyticus }\end{array}$ & $\begin{array}{l}\text { Isolated from a patient suffering from "Shirasu" } \\
\text { food poising, Japan }\end{array}$ & - & - \\
\hline CIP $107925^{\top}$ & V.coralliilyticus & $\begin{array}{l}\begin{array}{l}\text { Bleached tissue of coral, Pocillopora } \\
\text { damicornis, Zanzibar }\end{array} \\
\end{array}$ & - & - \\
\hline
\end{tabular}


Table 2: Nucleotide sequences and melting temperature $(\mathrm{Tm})$ of primers and probes designed for real-time PCR reaction.

\begin{tabular}{|lllll|}
\hline Gene & Function & Name & Sequence (5'-3') & $\operatorname{Tm~}$ ( $\left.^{\prime} \mathbf{C}\right)$ \\
\hline toxR & forward primer & ToxR F1 & cca-ctg-ctg-aga-caa-aag-ca & 60 \\
& $\begin{array}{l}\text { reverse primer } \\
\text { taqman probe }\end{array}$ & $\begin{array}{l}\text { ToxR R1 } \\
\text { parA }\end{array}$ & $\begin{array}{l}\text { gtg-att-ctg-cag-ggt-tgg-tt } \\
\text { cag-ccg-tcg-aac-aag-cac-cg }\end{array}$ & 60 \\
& $\begin{array}{l}\text { forward primer } \\
\text { reverse primer }\end{array}$ & ParA F1 & aag-gag-gct-cag-gaa-aaa-gc & 66 \\
& taqman probes & ParA P1 & $\begin{array}{l}\text { caa-tgc-aag-gga-tct-gag-gt } \\
\text { cag-cag-aat-ggg-cag-cgg-aa }\end{array}$ & 60 \\
& & & & 64 \\
\hline
\end{tabular}

\section{Figures}

Figure 1: Visualization of qPCR products in agarose gel using DNA from one ORM4 bacterial colony and specific primers and probes for parA (lane 1; $168 \mathrm{bp}$ ) and toxR (lane 2; $162 \mathrm{bp}$ ) genes. Lane MT corresponds to a size standard DNA ladder.

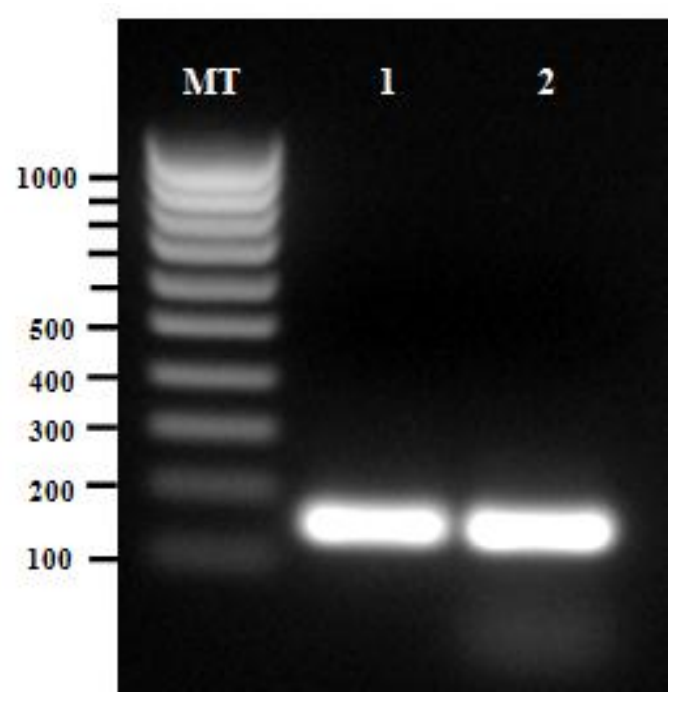


Figure 2. Standard curves for the detection and quantification of the tox $R$ gene by real-time PCR in 10-fold dilution range of SASW (solid line) or abalone haemolymph samples (dash line) artificially spiked with the virulent $V$. harveyi ORM4 bacterial strain. Standard curves were generated by plotting the log cell number of bacteria presents in PCR DNA template versus threshold cycle $(\mathrm{Ct})$ values.

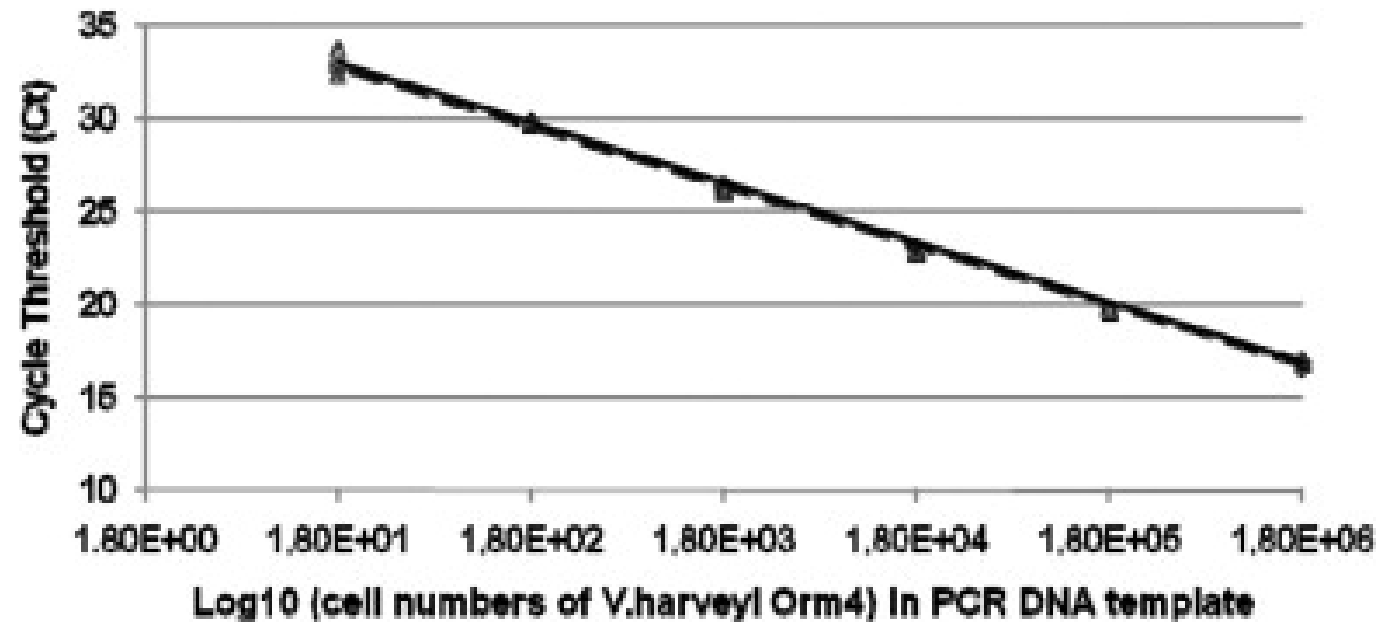

Figure 3: Standard curves for the detection and quantification of the parA plasmid gene by real-time PCR in 10-fold dilution range of SASW or abalone hemolymph samples artificially spiked with the virulent V. harveyi ORM4 bacterial strain. Standard curves were generated by plotting the log cell number of bacteria present in PCR DNA template versus threshold cycle (Ct) values.

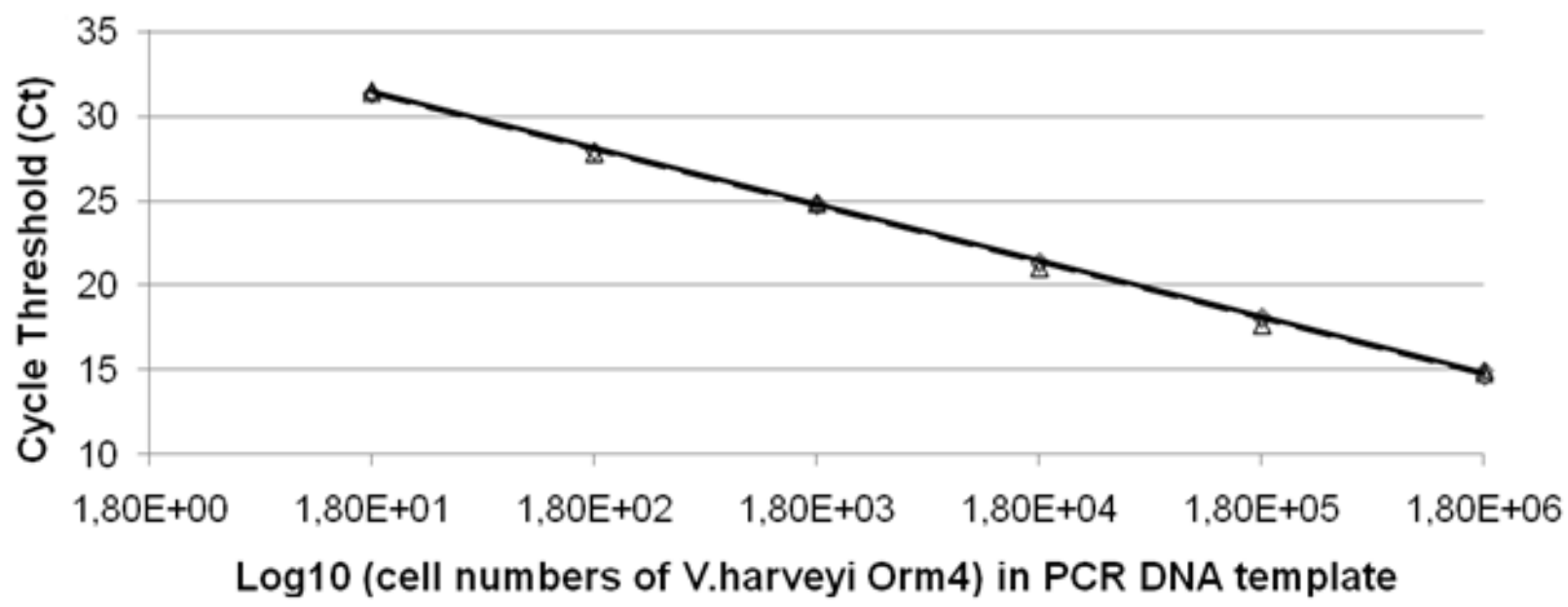


Figure 4: Kinetic of abalone infection by ORM4 V. harveyi strain by toxR real-time PCR in hemolymph samples withdrawn at $24,48,72,96$ and 120 post experimental challenge. The sensitivity threshold is indicated by the minimum value of the ordinate axis $(3.7 \times 103$ cells $\mathrm{mL}$ 1). Non-quantifiable ORM4-infected animals (data out of standard curve dilution limits) are represented by an asterisk.

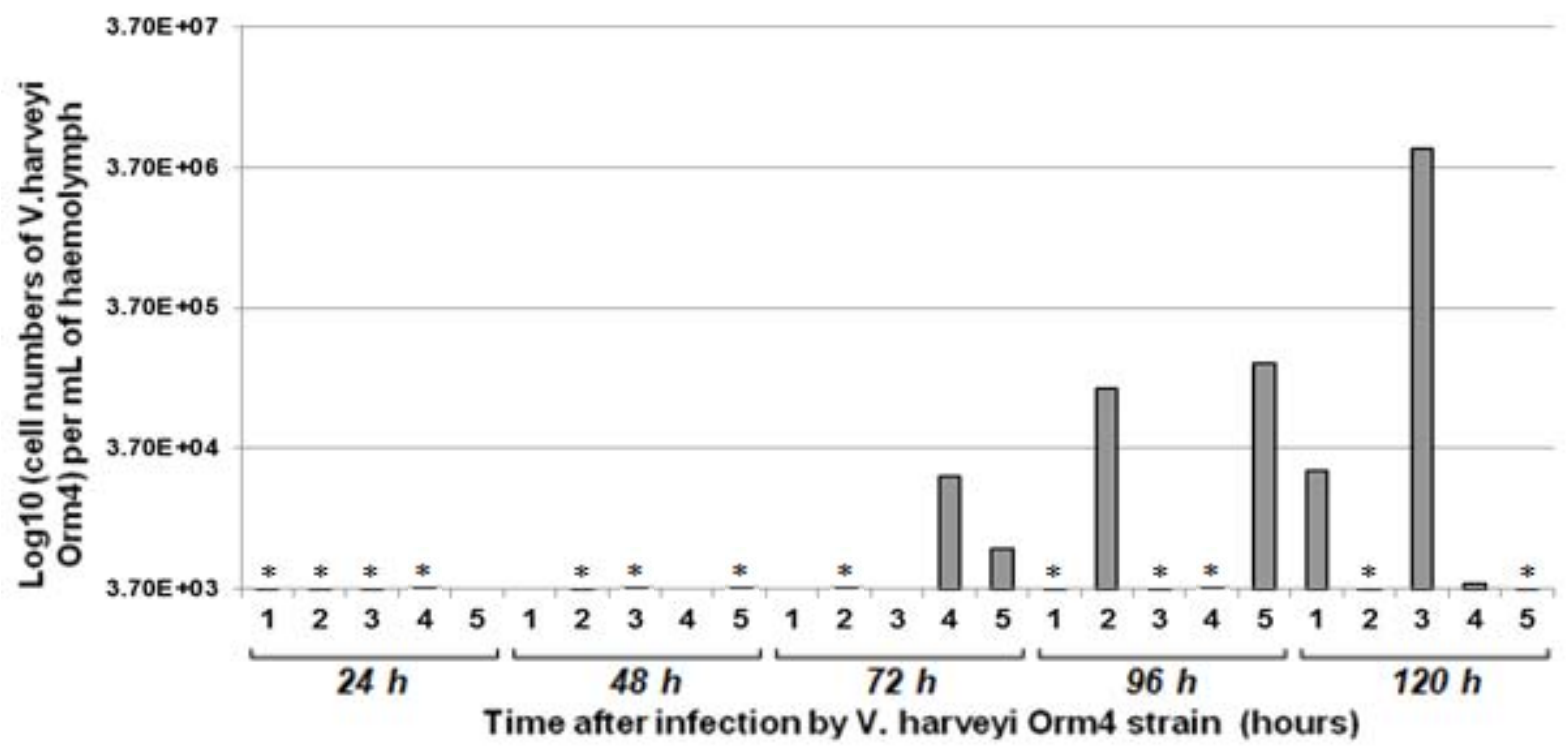

